\title{
UPAYA MENINGKATKAN KEPEDULIAN SOSIAL MELALUI SIMULASI GAME PADA SISWA SMK MATSARATUL HUDA PAMEKASAN
}

\author{
R. Ayu Arina Abida, Ishlakhatus Sa'idah \\ Fakultas Tarbiyah, IAIN Madura \\ Email: abidaarina2@gmail.com
}

\begin{abstract}
The purpose of this research is to know the effectiveness of the group counseling with simulation game technique to increase the social care of students X Class TKJ female SMK Matsaratul Huda Panempan Pamekasan, and to explore the significance of the group counseling with simulation game technique in increasing the social care of students X Class TKJ female SMK Matsaratul Huda Panempan Pamekasan.This study used a preexperimental design with a One-Group Pretest-Posttest Design. The method of collecting the data used is the method of questionnaires and interviews. And the data analysis technique used the Paired Sample T-test.The results of the study indicate that (1) Group guidance with game simulation techniques can increase the social awareness of class $X$ female TKJ students for the 2020/2021 academic year. This is evidenced based on the results of the t test, obtained t count $>$ t table $(7.174>1.753)$ at a significant level $=0.05$ with a value of Sig. (2-tailed) of 0.000. (2) Rated average pre-test of 107.88 and after given group guidance services with game simulation techniques, the post-test results increased to 115.31. So that, the increase amounted to 7, 43.
\end{abstract}

Keywords: Group Counseling, Simulation Game, Social Care

\begin{abstract}
Abstrak
Tujuan diadakannya penelitian ini adalah untuk mengetahui efektivitas bimbingan kelompok dengan teknik simulasi game dalam meningkatkan kepedulian sosial siswa kelas X TKJ Putri SMK Matsaratul Huda Panempan Pamekasan tahun ajaran 2020/2021 dan signifikansi bimbingan kelompok dengan teknik simulasi game dalam meningkatkan kepedulian sosial siswa kelas X TKJ Putri SMK Matsaratul Huda Panempan Pamekasan tahun ajaran 2020/2021.Penelitian ini menggunakan rancangan pre-eksperimen dengan desain One-Group Pretest-Posttest Design. Dan teknik analisis data menggunakan uji Paired Sample T-test.Dari hasil penelitian menunjukkan bahwa (1) Bimbingan kelompok dengan teknik simulasi game dapat meningkatkan kepedulian sosial siswa kelas X TKJ putri tahun ajaran 2020/2021. Ini dibuktikan berdasarkan hasil uji $t$ diperoleh $t$ hitung $>t$ tabel $(7,174>$ 1,753) pada taraf signifikan $\alpha=0,05$ dengan nilai Sig. (2-tailed) sebesar 0,000. (2) Nilai rata-rata pre-test sebesar 107,88 dan setelah diberikan layanan bimbingan kelompok dengan teknik simulasi game hasil post-test meningkat menjadi 115,31. Sehingga peningkatannya sebesar 7,43.
\end{abstract}

Kata Kunci :Bimbingan Kelompok, Simulasi Game, Kepedulian Sosial

\section{PENDAHULUAN}

Kodrat manusia adalah sebagai makhluk sosial. Artinya, manusia sulit untuk bertahan hidup seorang diri melainkan adanya bantuan dari individu lainnya untuk bertahan dan melangsungkan kehidupannya. Keadaan sosial secara tidak langsung menuntut manusia untuk saling hidup berdampingan dan ketergantungan. Maka, seyogyanya kita juga dituntut sukarela menolong dan 
memberikan bantuan kepada orang lain, perilaku seperti ini sering disebut sebagai kepedulian sosial.

Kepedulian sosial adalah salah satu bagian dari syariat Islam yang sudah diperankan oleh junjungan besar yakni Nabi Muhammad Shallallahu 'Alaihi Wasallam, dalam fatwanya: "Budi pekerti yang luhur termasuk salah satu amalan ahli surga (Sonny, 2015). Dalam konteks ini kepedulian sosial memang sangat dianjurkan kepada seluruh umat Muslim, kita dianjurkan untuk saling menjaga solidaritas dengan cara saling membantu antar saudara muslim.

Berikut hadis yang diriwayatkan dari Abu Hurairah RA, beliau berkata: Rasulullah SAW bersabda:

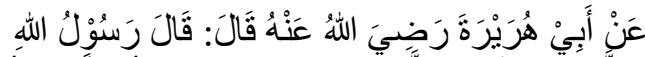

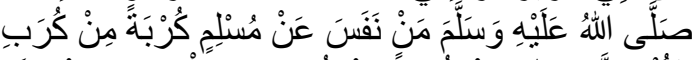

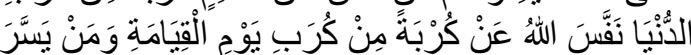

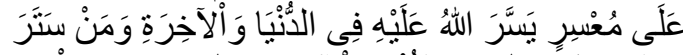

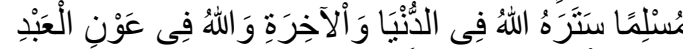

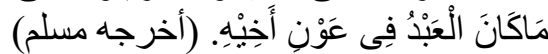

Yang artinya "Abu Hurairah berkata, Rasulullah SAW. bersabda, barangsiapa melepasakan dari seorang muslim satu kesusahan dari kesusahan-kesusahan di dunia, niscaya Allah akan melepasakan dia dari kesusahan-kesusahan hari kiamat; dan barangsiapa memberi kelonggaran kepada orang yang susah, niscaya Allah akan memberi kelonggaran-kelonggaran baginya di dunia dan akhirat; dan barangsiapa menutupi aib seorang muslim, niscaya Allah akan menutupi aib dia dunia dan akhirat; Allah akan senantiasa menolong hamba-nya selama hambanya tersebut menolong saudaranya." (H.R. Muslim) (Habibi, 2019).

Menurut Adler (2002), kepedulian sosial dapat didefinisikan sebagai sebuah sikap keterhubungan dengan kemanusiaan pada umumnya, sebuah empati bagi setiap anggota komunitas manusia yang memanifestasikan diri sebagai kerjasama dengan orang lain demi kemajuan sosial, lebih daripada perolehan pribadi semata.

Mengenai perilaku peduli terhadap sesama banyak kita temui pada lingkungan sekitar. Perilaku peduli yang dimaksudkan bukan dalam artian untuk ikut campur dalam permasalahan orang lain, melainkan menolong dalam meringankan beban dari masalah yang dihadapi oleh seseorang dengan berlandaskan keikhlasan yang bertujuan untuk kebaikan dan perdamaian (Tabi'in, 2017). Hal tersebut sudah jelas bahwasanya kepedulian sosial yakni perilaku yang mencerminkan kepedulian dalam ranah membantu menyelesaikan masalah dengan tujuan kebaikan.

Sikap peduli dalam diri memang tidak bisa muncul secara langsung dalam seseorang terutama pada siswa, maka dari itu diperlukannya proses melatih dan mendidik baik dari lingkungan. Keluarga adalah lembaga pendidikan pertama dan utama bagi siswa.Dari lingkungan keluarga inilah yang pertama kali anak dikenalkan dan menerima pendidikan dan pengajaran terutama dari ayah dan Ibunya (Hasanuddin, 2016). Tidak hanya di lingkungan keluarga, melainkan lingkungan masyarakat maupun lingkungan sekolah juga dekat dengan siswa. Dimana ketiga aspek tersebut tempat tumbuh berkembang dan bersosialisasi siswa.

Selain lingkungan keluarga yang tupoksinya menjadi bekal utama ilmu peserta didik, juga terdapat sekolah yang menjadi pengaruh cukup besar dalam perkembangan siswa. Era baru ini pemerintah telah berusaha mengaplikasikan pendidikan di Indonesia yaitu pendidikan karakter. Pendidikan karakter bangsa ini dipandang urgent, murid atau siswa tidak hanya harus dicerdaskan dibidang intelektual dan emosional, namun juga tercipta pribadi yang unggul dan berakhlak mulia dengan mengembangkan kepribadian (karakter) positif bagi peserta didik.

Minimnya perilaku kepedulian sosial antara siswa dengan temannya akan berdampak pada menghambatnya perkembangan sosialisasi atau interaksi sosial dalam pergaulan di lingkungan sekolah, sehingga dikhawatirkan siswa akan cenderung memiliki sifat yang hanya memikirkan dirinya sendiri. Kepedulian sosial disini dapat dibagi menjadi dua 
macam yakni hablum minannas dan hablum minal alam. Maksudnya kepedulian sosial ini tidak hanya diberlakukan dengan sesama manusia melainkan juga dengan alam sekitar.

Berdasarkan hasil wawancara peneliti dengan salah satu guru mata pelajaran di sekolah tersebut siswa disana dapat dikategorikan memiliki kepedulian sosial yang rendah. Siswa disana cenderung membeda-bedakan teman antara santriwati dan non santriwati. Jika hal ini tidak ditangani atau dibiarkan maka akan berdampak buruk bagi siswa seperti halnya kurangnya rasa solidaritas antar teman, minimnya rasa empati dan toleransi, serta adanya sikap acuh tak acuh di dalam kelas sehingga dikhawatirkan akan berdampak pula kepada kegiatan belajar di dalam kelas.

Salah satu cara untuk membentuk dan mengembangkan kepedulian sosial siswa yakni dapat ditangani melalui layanan bimbingan dan konseling. Sebagai salah satu dari elemen dari sekolah, guru BK mempunyai peranan dalam hal tersebut. Bimbingan dan konseling adalah suatu proses bantuan oleh seorang ahli yang disebut konselor, kepada peserta didik atau individu (klien) bahkan bisa dalam bentuk berkelompok dengan cara yang profesional. Tujuannya untuk membantu dalam menangani permasalahan klien tersebut agar terciptanya hidup yang mandiri sehingga dapat menentukan pilihan dan memahami dirinya (Hallen, 2002).

Guru BK atau Konselor mempunyai program dan layanan-layanan, salah satunya yakni layanan bimbingan kelompok. Layanan bimbingan kelompok merupakan proses pemberian bantuan berupa bimbingan terhadap klien (siswa) dalam bentuk berkelompok. Dalam bimbingan kelompok, keaktifan serta dinamika kelompok harus dibangun agar membantu berbagai hal untuk digunakan sebagai solusi dari permasalahan klien (siswa) dalam kegiatan bimbingan.

Dasarnya bimbingan kelompok memiliki tujuan sebagai pengembangan keterampilan dalam interaksi sosial, khususnya kemampuan bersosialisasi dan komunikasi siswa. Sedangkan secara khusus, bimbingan kelompok memiliki tujuan untuk mewujudkan terciptanya perasaan, pemikiran, persepsi, wawasan, serta perilaku yang menunjang terciptanya perilaku yang lebih efektif (Hallen, 2002). Maka dari itu bimbingan kelompok bisa membantu siswa khususnya dalam bersosialisasi dengan orang lain dan dapat mengembangkan beberapa aspek serta dapat mengubah perilaku individu sesuai norma dalam masyarakat.

Dalam bimbingan kelompok ada beberapa teknik, salah satu diantaranya yaitu teknik permainan (simulasi game). Simulasi game merupakan salah satu dari beberapa macam teknik simulasi. Simulasi game adalah bermain peran, para siswa berlomba untuk memenangkan permainan dengan berpedoman oleh peraturan yang ada (Abdul, 2014). Permainan simulasi dapat dikatergorikan kolaborasi antara teknik bermain peran dan teknik diskusi kelompok. Dimana nantinya dalam permainan ini kelompok akan saling bertukar pikiran sehingga bisa mengembangkan ilmu, perilaku, dan keahlian siswa dalam mengahadapi berbagai situasi sosial yang problematis.

Dalam penelitian ini terdapat dua permainan yakni ular tangga dan kapal karam. Dimana dalam permainan ular tangga mempunyai topik pembahasan mengenai kepedulian sosial sedangkan dalam permainan kapal karam mempunyai topik pembahasan mengenai kerjasama, gotong royong, dan sopan santun. Dan dalam penelitian ini juga terdapat tugas rumah yakni siswa mencatat perilaku kepedulian sosial yang telah dilakukan dalam kurun waktu 1 minggu.

Adapun beberapa penelitian terdahulu yang dijadikan pertimbangan dalam penelitian ini yaitu penelitian Silva Ardiyanti (2017) mengenai layanan bimbingan kelompok teknik role playing terhadap kepedulian sosial sesama teman sebaya memperoleh hasil bahwasanya ada pengaruh dalam penelitiannya yakni terdapat 
perbedaan skor antara sebelum dan sesudah diberi treatment. Annisa Nur Khoiriyah (2018) mengenai bimbingan kelompok dalam meningkatkan kepedulian sosial siswa memperoleh hasil bahwasanya upaya guru BK yang dilakukan dalam meningkatkan kepedulian siswa dengan tahapan-tahapan bimbingan kelompok berjalan dengan baik dan siswa dapat meningkatkan kepedulian sosial terhadap lingkungan sekitarnya.

Adapun tujuan dalam penelitian ini adalah: 1) untuk mengetahui efektivitas bimbingan kelompok dengan teknik simulasi game dalam meningkatkan kepedulian sosial siswa. 2) untuk mengetahui signifikansi bimbingan kelompok dengan teknik simulasi game dalam meningkatkan kepedulian sosial siswa.

\section{METODE PENELITIAN}

Penelitian ini menggunakan pendekatan kauntitatif dengan rancangan preexperimental one-group pretest-posttest design. Tujuan digunakan jenis rancangan one-group pretest-posttest design ini yaitu untuk mempengaruhi kelompok eksperimen yakni tentang efektivitas bimbingan kelompok dengan teknik simulasi game untuk meningkatkan kepedulian sosial siswa kelas X TKJ putri dengan mengetahui perbedaan skor pretest dengan skor posttest. Dengan demikian hasil perlakuan dapat diketahui lebih akurat karena dapat membandingkan dengan keadaan sebelum dan setelah diberi perlakuan (treatment).

Gambar 1. Rancangan penelitian

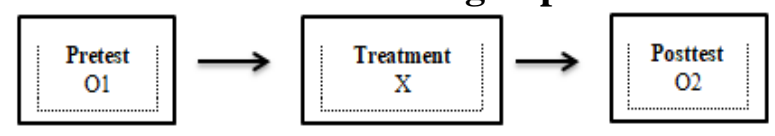

Keterangan :

O1 : Kepedulian sosial sebelum diberi perlakuan (Pretest)

$\mathrm{X}$ : Bimbingan kelompok teknik simulasi game (Treatment)

$\mathrm{O} 2$ : Kepedulian sosial setelah diberi perlakuan (Posttest)

Sampel yang digunakan sebanyak 16 siswa dengan menggunakan teknik puposive sampling dari populasi 121 siswa yakni jumlah keseluruhan dari siswa SMK Matsaratul Huda Panempan Pamekasan Tahun Ajaran 2020/2021. Instrumen yang digunakan dalam penelitian ini yaitu skala kepedulian sosial siswa dan wawancara. Skala pengukuran instrumen yang digunakan adalah model skala Likert. Skala Likert digunakan untuk mengukur sikap, pendapat, dan persepsi seseorang atau sekelompok orang tentang fenomena sosial (Sugiyono: 2010).

Tabel 1

\section{Pemeberian Skor Angket Berdasarkan} Skala Likert

\begin{tabular}{|l|c|c|c|c|c|}
\hline Pernyataan & SS & S & KS & TS & STS \\
\hline Positif (favorable) & 5 & 4 & 3 & 2 & 1 \\
\hline $\begin{array}{l}\text { Negatif } \\
\text { (unfavorable) }\end{array}$ & 1 & 2 & 3 & 4 & 5 \\
\hline
\end{tabular}

Keterangan :

SS : Sangat Sesuai

$S$ : Sesuai

KS : Kurang Sesuai

TS : Tidak Sesuai

STS: Sangat Tidak Sesuai

Uji coba instrumen menggunakan uji validitas dan reliabilitas. Penelitian ini menggunakan uji validitas Corrected ItemTotal Correlation yang dapat dilihat pada table Item-Total Statistics dengan syarat nilai koefisien validitas $\geq 0,36$ (dikonsultasikan dengan $\mathrm{r}_{\text {tabel }}$ dengan taraf signifikan $5 \%$ ). Untuk reliabilitas Secara keseluruhan diperoleh hasil $\mathrm{r}_{\text {hitung }}=0,810$ dengan $\mathrm{N}=60$ pada taraf signifikan 5\% dan rtabel 0,36. Dengan demikian $r_{\text {hitung }}=0,81>r_{\text {tabel }} 0,36$. Untuk uji prasyarat menggunakan uji normalitas.Dan teknik analisis data menggunakan uji Paired Sample T-test (uji sampel berpasangan). Uji ini merupakan uji hipotesis komparatif atau uji perbandingan. Bertujuan untuk mengetahui apakah terdapat perbedaan rata-rata dua sampel (dua kelompok) yang saling berpasangan atau berhubungan yaitu tingkatkepedulian social pada saat pre-test dengan post-test.

\section{HASIL DAN PEMBAHASAN}

Tabel 2

Tabel hasil Paired Samples Test 


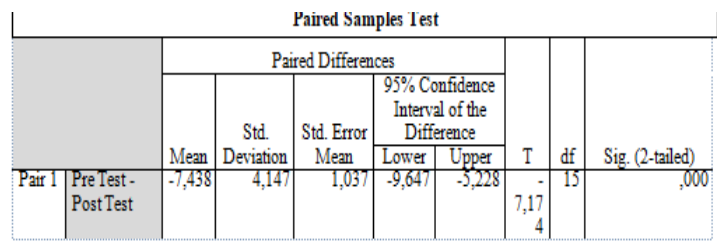

$\operatorname{di}_{r}$

adalah sebesar $-7,438$ nilai ini adalah selisih antara rata-rata nilai pre-test dan post-test serta diketahui juga bahwa Sig. (2-tailed) sebesar 0,000. Singgih Santoso (2014) dasar pengambilan keputusan dalam Uji Paired Sample T-Test berdasarkan nilai Sig. yaitu sebagai berikut:

a) Apabila skor Sig. (2-tailed) $<0,05$ maka Ha diterima sedangkan Ho ditolak.

b) Apabila skor Sig. (2-tailed) > 0,05 maka Ha ditolak sedangkan Ho diterima.

Dalam Uji Paired Sample T-Test diatas diketahui bahwa nilai sig. (2-tailed) sebesar 0,000 yang berarti kurang dari 0,05 maka artinya ada perbedaan yang bermakna dari hasil rata-rata pre-test dan post-test.

Tabel 3

Tabel hasil Paired Samples Statistics

\begin{tabular}{|l|l|r|r|r|r|}
\hline \multicolumn{7}{|c|}{ Paired Samples Statistics } \\
\hline \multirow{3}{*}{ Pair 1 } & Mean & \multicolumn{1}{c|}{ N } & Std. Deviation & Std. Error Mean \\
\cline { 2 - 6 } & Post Test & 107,88 & 16 & 8,617 & 2,154 \\
& & 115,31 & 16 & 8,577 & 2,144 \\
\hline
\end{tabular}

Berdasarkan Uji Paired Samples Statistics diperoleh hasil rata-rata nilai pretest sebesar 107,88 dan rata-rata nilai posttest sebesar 115,31. Diketahui bahwa ratarata nilai post-test lebih tinggi dibanding rata-rata nilai pre-test yang menunjukkan bahwa ada perubahan skor yang bermakna dari hasil treatment yang berarti bimbingan kelompok dengan teknik simulasi game efektif untuk meningkatkan kepedulian sosial siswa.

\section{Diagram Batang Hasil Pre-Test dan Post- Test Skala Kepedulian Sosial}

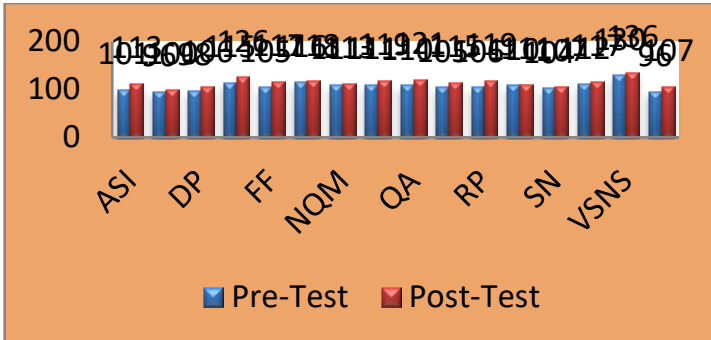

Dari diagram di atas dapat disimpulkan bahwa terdapat perbedaan skor kepedulian sosial. Untuk grafik post-test secara umum lebih tinggi dibanding pre-test, hal ini berarti terdapat perbedaan skor antara hasil pre-test dengan post-test setelah diberikan treatment bimbingan kelompok dengan teknik simulasi game.

\section{Tabel 3}

Tabel hasil Paired Samples Correlation

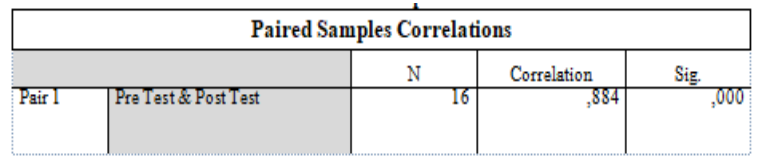

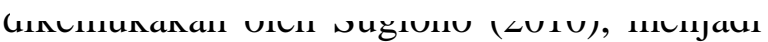
dasar untuk mengetahui interpretasi dari tingkat kekuatan hubungan, yaitu sebagai berikut:

Tabel 4

Pedoman Interpretasi Koefisien Korelasi Interval Koefisien $\quad$ Tingkat Hubungan

\begin{tabular}{c|c}
\hline $0,00-0,199$ & Sangat rendah \\
\hline $0,20-0,399$ & Rendah \\
\hline $0,40-0,599$ & Sedang \\
\hline $0,60-0,799$ & Kuat \\
\hline $0,80-1,000$ & Sangat kuat
\end{tabular}

Dari hasil Uji Paired Samples Correlations diketahui bahwa nilai korelasi sebesar 0,884 yang artinya nilai tersebut membuktikan adanya korelasi yang sangat kuat antara layanan bimbingan kelompok dengan teknik simulasi game dalam meningkatkan kepedulian sosial. Serta diketahui nilai Sig. 0,000 yang diperoleh yakni $<0,05$ yang berarti ada perbedaan yang bermakna pada skor kepedulian sosial yang dilihat dari nilai pre-test dan post-test.

Penelitian dilaksanakan empat kali pertemuan. Pertemuan pertama merupakan penyebaran soal pre-test pada siswa untuk 
mengetahui tingkat kepedulian sosial awal siswa dan juga pembagian materi guna dipelajari oleh siswa. Dan pada pertemuan kedua sampai ketiga melaksanakan bimbingan kelompok teknik simulasi game. Kemudian pada pertemuan terakhir yaitu penyebaran soal post-test.

$$
\text { Adapun treatment dalam }
$$

penyelenggaraan bimbingan kelompok teknik simulasi game ini terdapat dua jenis permainan (game) yaitu permainan ular tangga dan kapal karam. Pada permainan ular tangga ini merupakan permainan inti karena membahas mengenai kepedulian sosial secara mendalam. Sedangkan permainan kedua yaitu permainan kapal karam merupakan permainan tambahan yang membahas mengenai kerjasama, gotongroyong, dan sopan santun. Maksud peneliti merancang permainan tersebut yaitu agar siswa dapat lebih memahami dan juga agar siswa dapat mengaplikasikan secara langsung mengenai kerjasama, gotongroyong dan sopan santun yang memang merupakan bagian dari kepedulian sosial.

Pada pertemuan pertama, suasana bimbingan terlihat kaku ini dikarenakan siswa masih terlihat malu, akan tetapi pada sesi permainan mereka sudah mulai tanpak bersemangat. Sebagian dari mereka antusias untuk menjawab pertanyaan yang ada pada kartu pesan permainan. Dan pada sesi permainan juga semakin terlihat bersemangat dan sangat antusias. Dalam pertemuan pertama ini permainan yang dimainkan yaitu permainan ular tangga. Di dalam permainan ini sudah ditentukan beberapa siswa yang bermain dan memerankan peranan yang sudah ditentukan. Setelah games selesai, masing-masing dari mereka mengutarakan pendapatnya dan memberikan kesimpulan hasil tentang materi yang dibahas berhubungan dengan games yang telah dimainkan.

Pada pertemuan selanjutnya yakni permainan kapal karam, dalam games mereka semakin terlihat nyaman. Mereka sudah semakin tidak malu lagi untuk berkompetisi dan memenangkan permainan tersebut. Mereka terlihat antusias dan menunjukkan bahwasanya mereka tertarik dan berminat untuk berpartisipasi dalam kegiatan bimbingan kelompok teknik simulasi game ini tanpa keterpaksaan. Hal tersebut terbukti ketika membahas materi dan melakukan teknik games yang telah disediakan oleh peneliti, mereka memberikan respon yang baik ini dibuktikan dari ekspresi mereka yang sangat senang dan tenang. Setelah permainan ini selasai seperti biasa siswa diminta untuk menyimpulkan kesimpulan dan pendapat mengenai hasil dari kegiatan permainan.Pada pertemuan ini juga siswa diberikan tugas rumah yaitu mencatat perilaku kepedulian sosial selama satu minggu guna mengetahui realitas perilaku kepedulian siswa setelah mereka melakukan treatment berupa permainan.

Sehingga pada pertemuan terakhir peneliti meminta siswa untuk mengumpulkan hasil catatan kegiatan perilaku sosial selama satu minggu.Hasil yang didapat siswa terbilang baik dalam menerapkan perilaku peduli sosial baik di lingkungan keluarga, masyarakat, dan sekolah. Siswa diharap memeiliki sikap kepedulian sosial yang selaras dengan pendapat Achmad (2017) bahwasanya peduli sosial adalah sikap dan tindakan yang selalu ingin memberi bantuan kepada masyarakat yang membutuhkan. Sehingga menjadikan siswa selalu bergerak untuk membantu orang lain yang membutuhkan.

Siswa juga diminta untuk mengutarakan kesan dan perasaannya setelah melakukan perilaku peduli sosial, mereka merespon dengan baik mereka merasakan feedback positif seperti hati terasa tenang.Dan berdasarkan dari hasil wawancara dengan guru mata pelajaran juga diperoleh hasil yang baik. Beliau berpendapat bahwa terdapat perbedaan yang sangat signifikan terhadap kepedulian sosial siswa, salah satu contohnya yaitu siswa tidak lagi membedakan teman, mampu bekerja sama dan saling peduli antar teman.

\section{KESIMPULAN}


Hasil penelitian menunjukkan bahwa bimbingan kelompok dengan teknik simulasi game bisa meningkatkan kepedulian sosial siswa kelas X Teknik Komputer Jaringan (TKJ) putri tahun ajaran 2020/2021. Ini dibuktikan berdasarkan hasil uji $\mathrm{t}$ diperoleh $\mathrm{t}$ hitung $>t$ tabel $(7,174>1,753)$ pada taraf signifikan $\alpha=0,05$ dengan nilai Sig. (2tailed) sebesar 0,000. Sehingga $\mathrm{H}_{0}$ ditolak dan $\mathrm{H}_{\mathrm{a}}$ diterima yang artinya bimbingan kelompok dengan teknik simulasi game efektif untuk meningkatkan kepedulian sosial siswa kelas X TKJ putri.

Pada hasil analisis data instrumen penelitian, ditemukan bahwa nilai rata-rata pre-test sebesar 107,88 dan setelah diberikannya layanan bimbingan kelompok dengan teknik simulasi game hasil post-test meningkat menjadi 115,31. Sehingga peningkatannya sebesar 7,43. Diketahui bahwa rata-rata nilai post-test lebih tinggi dibanding rata-rata nilai pre-test serta tingkat korelasi yang diperoleh sebesar 0,884 sehingga dapat disimpulkan ada pengaruh yang kuat antara layanan bimbingan kelompok dengan teknik simulasi game terhadap kepedulian sosial siswa kelas $\mathrm{X}$ TKJ putri SMK Matsaratul Huda Panempan Pamekasan. Dan ini juga dipekuat dengan adanya hasil wawancara dengan guru mata pelajaran bahwasanya siswa sudah mulai menerapkan sikap kepedulian sosial salah satu contoh yakni siswa tidak lagi membedabedakan teman dan saling solid satu sama lain.

\section{REFERENSI}

Aminuddin, Djoni dan Mulyadi. 2019. Efektivitas Layanan Informasi Karir dalam Meningkatkan Kemampuan Perencanaan Karir Siswa.Consilium Berkala Kajian Konseling dan Ilmu Keagamaan 6, no. 2.
Arikunto, Suharsimi. 2013. Prosedur Penelitian Suatu Pendekatan Praktik. Jakarta: Rineka Cipta.

Ayuni, Rizka Rosida dan Elia Flurentin. 2016. Pengembangan Panduan Sosiodrama untuk Meningkatkan Kepedulian Sosial Siswa SMP. Jurnal Kajian Bimbingan dan Konseling. Malang.

Fauzi, Achmad Ryan, dkk. 2017. Penguatan Karakter Rasa Ingin Tahu dan Peduli Sosial Melalui Discovery Learning. Jurnal Teori dan Praktis Pmebelajaran IPS. Malang.

Hallen. 2002. Bimbingan dan Konseling dalam Islam. Jakarta: Ciputat Pers.

Hasanudin, dkk. 2016. Hubungan Prestasi Belajar Mata Pelajaran Pendidikan Agama Islam (PAI) dengan Kepedulian Sosial Siswa Kelas XI Sekolah Menengah Atas (SMA) Negeri 1 Darma Desa Cipasung Kecamatan Darma Kabupaten Kuningan. Jurnal Al Tarbawi Al Haditsah. Cirebon.

Mulyawati, Hanny dkk. 2015. Pembelajaran Studi Sosial. Bandung: Alfabeta.

Rahayu, Muji. 2017. Penerapan Permainan Simulasi sebagai Teknik Bimbingan Kelompok untuk Meningkatkan Kemampuan Menyelesaikan Konflik di SMK Negeri 1 Polewali. Jurnal Pendidikan Islam: Pendekatan Interdisipliner. Polewali.

Sudarto, dkk. 2019. Bunga Rampai (Pendidikan Agama Islam). Kalimantan Tengah: CV. Narasi Nara.

Sugiyono. 2010. Metode Penelitian Kuantitatif, Kualitatif, dan $R \& D$. Bandung: Alfabeta.

Tabi'in, A. 2017. Menumbuhkan Sikap Peduli pada Anak melalui Interaksi Kegiatan Sosial. Journal of Social Science Teaching. Pekalongan. 